УДК 81’33

\author{
И.А. Синицына, М.А. Сафонов, С.С. Усов, Н.Л. Харченко, Е.А. Янова
}

\title{
ЯЗЫКОВЫЕ СРЕДСТВА ВЫРАЖЕНИЯ ЭЛЕМЕНТОВ ФАНТАСТИКИ В ПОЛИТИЧЕСКОМ ДИСКУРСЕ
}

В данной статье рассматривается категория фантастического в политическом дискурсе - ее языковое выражение и причины появления. В процессе исследования выяснилось, что одним из важнейших языковых средств выражения фантастического в политическом дискурсе является метафора и все ее проявления в тексте. С помощью метафор передается особое, фантастическое восприятие мира. Но помимо метафор формированию категории фантастического способствует употребление метонимий, гипербол, литот, сравнений, эпитетов и др. Использование элементов фантастического в политическом дискурсе мы рассмотрим на примере знаменитой книги «Максимы и мысли узника Святой Елены», в которой граф Лас Каз, добровольно последовавший за Наполеоном Бонапартом в егоизгнание, запечатлел высказывания императора, его меткие афоризмы, фрагменты политических речей и т.д. Наполеон Бонапарт создавал авторские мифы о себе, своем правлении и своей армии (Великая Армия, Grande Armee), запечатленные в его политических речах, письмах, максимах и обращениях к солдатам и современникам. В плане литературном и языковом представляет интерес сама форма, выбранная Наполеоном для выражения своих политических и философских суждений - максимы, афоризмы.

Итогом нашего исследования стало выявление категории фантастического в политическом дискурсе наполеоновской эпохи, оформленного с помощью метафор, эпитетов, гипербол, гротеска, олицетворений, особых сравнений и повторов, а также аллюзий, реминисценций, явного и скрытого цитирования.

Ключевые слова: политический дискурс, категория фантастичности, метафора, французский язык.

DOI: 10.35634/2412-9534-2021-31-2-254-263

Фантастику и фантастическое мы понимаем, как описание и выражение сверхъестественного, необыкновенного, необычного. В семантике текста и в литературоведении фантастическое понимается как построение, создание идей, образов и символов с опорой на существование некоего вымышленного автором волшебного мира, как изображение странного и неправдоподобного. В результате создается некое двоемирие: бытие делится на реальное и фантастическое, волшебное. Фантастический мир может существовать в некоем волшебном, идеальном пространстве или в идеальном, «золотом» времени.

Для политического дискурса характерно изображение идеального, неправдоподобного пространства или времени («светлого будущего», идеальной «Страны Советов», идеальной России и т.д.). В этом фантастическом пространстве или времени якобы не существует проблем или недостатков: политики стремятся уверить аудиторию в том, что, благодаря определенной сумме действий их самих или их партий, это идеальное время (золотой век) очень быстро наступит.

Собственно говоря, фантастическое в политическом дискурсе тесно связано с утопическим мышлением, с изображением утопии - идеального государства, общества или эпохи. Утопия - это нечто фантастическое, несбыточная, неосуществимая мечта [13, с. 22]. Утопия как жанр восходит к одноименному произведению Томаса Мора - «Золотая книжечка, столь же полезная, сколь и забавная о наилучшем устройстве государства и о новом острове Утопия». В значении «модель идеального общества» это слово встречается в книге путешествий английского священника Сэмюэла Перчеса «Паломничество».

Фантастическая образность присуща практически всем жанрам политического дискурса и формируется на основании использования таких средств художественной выразительности, как метафоpa, гипербола, литота, гротеск, сравнение, метонимия, аллегория, персонификация, образный параллелизм и т.д. К средствам выражения фантастического также относятся аллюзии, эпитеты, иногда крылатые выражения, пословицы и поговорки [6, с. 34].

Одним из важнейших языковых средств выражения фантастического в политическом дискурсе является метафора. Д. Дэвидсон писал: «Метафора - это греза, сон языка («dream work of language»). Толкование снов нуждается в сотрудничестве сновидца и истолкователя, даже если они сошлись в одном лице. Точно так же истолкование метафор несет на себе отпечаток и творца, и интерпретатоpa» $[6$, c. 34]. 
Языковые средства выражения элементов фантастики в политическом дискурсе

С.И. Ожегов в «Толковом словаре русского языка» называет метафорой вид тропа или скрытое образное уподобление [13, с. 368]. Метафоры могут быть простыми, одночленными или двучленными. Метафора, основанная на преувеличении, называется гиперболической. Гиперболические метафоры особенно часто используются в политическом дискурсе. Согласно Дж. Лакоффу и М. Джонсону, простая метафора выражена одним образом, но при этом не обязательно является однословной (например, «его глаза приклеились» или «попадает ему на глаза») [8, с. 84].

Развернутая или расширенная метафора состоит из нескольких метафорически употребленных слов. Эти слова создают единый образ. Развернутая метафора может представлять собой ряд дополняющих друг друга простых метафор.

Выделяются также традиционные метафоры, общепринятые в какой-либо период или в какомлибо литературном направлении (например, «кораллы уст», «звезды глаз» и т.д.)

Для метафорического эпитета характерны двуплановость, указание на сходство и несходство, семантическое рассогласование. Существуют анимистические метафорические эпитеты, когда неодушевленному предмету приписывается свойство живого существа. Антропоморфные метафорические эпитеты, напротив, приписывают человеческие характеристики и свойства животному.

В семантике текста и литературоведении выделяют также композиционную или сюжетную метафору. Такая метафора распространяется на весь текст (например, уподобление жизни театру, а героев - актерам).

Итак, метафора - это риторическое выразительное средство, характерное, конечно же, и для политического дискурса. Некоторые метафоры становятся метафорическими понятиями (концептами): например, концепт «Жизнь», концепт «Смерть», концепт «Справедливость» и т.д.

«Метафора - самый емкий троп. Она способна высветить с совершенно новой, необычной стороны предмет или явление, сделать текст неповторимо поэтическим. Метафоричность - одно из главных свойств художественного, словесно-образного мышления», - пишет Э.Я. Фесенко [15, с. 154]. Исследовательница продолжает: «В метафорах проявляется способность художественного слова открывать новые соотношения смысловых, реальных понятий. Метафора - не простое сравнение, а сравнение, доведенное до такой степени близости сравниваемых предметов, что они как бы полностью сливаются друг с другом в воображении автора». Она указывает также на то, что метафоры бывают простые и развернутые. Развернутыми называются метафоры, в которых метафорический образ охватывает текст целиком или несколько фраз, или периодов. Таковы, например, образ птицы-тройки в поэме Н.В. Гоголя «Мертвые души» или же образ «телеги жизни» в одноименном стихотворении А.С. Пушкина.

Далее мы рассмотрим использование языковых средств выражения фантастического (метафор, метонимий, гипербол, литот, сравнений, эпитетов и проч.) в политическом дискурсе и обратим особенное внимание на метафору.

С помощью метафор передается фантастическое восприятие мира. Метафора является носителем того смыслового содержания, которое вкладывают в нее политтехнологи (создатели политических текстов). Благодаря этому особому смысловому содержанию метафор осуществляется влияние на сознание и подсознание аудитории. Создаются авторские смыслы метафор, связанные с категорией фантастического, возникает особое семантическое пространство, общее для адресанта (отправителя сообщения) и адресата (получателя сообщения).

Использование элементов фантастического в политическом дискурсе мы рассмотрим сначала на примере знаменитой книги «Максимы и мысли узника Святой Елены», в которой граф Лас Каз, добровольно последовавший за Наполеоном Бонапартом в его изгнание, запечатлел высказывания императора, его меткие афоризмы, фрагменты политических речей и т.д. Существует еще одна книга Лас Каза, которую называют «Библией бонапартистов». Это «Мемориал Святой Елены» - книга, с которой не расставался главный герой романа Стендаля «Красное и черное» Жюльен Сорель.

Впервые «Мемориал Святой Елены» увидел свет в 1823-1824 гг. Он неоднократно переиздавался и переиздается в наше время - как на французском, так и в переводах на иностранные языки (в том числе и на русский). Эту книгу называли и называют «Библией бонапартистов». «Мемориал Святой Елены» во многом способствовал формированию «наполеоновского мифа», построенного, бесспорно, на различных элементах фантастического. В частности, к числу таких фантастических элементов,нашедших свое отражение в языке, можно отнести формирование сверхъестественного ореола вокруг личности императора, гиперболизацию его отдельных свойств и качеств, представление о нем как о непогрешимом, идеальном властителе и полководце, свергнутом с престола исключительно благодаря английским интригам и английскому золоту. 
Однако за год до смерти Наполеона в Париже была выпущена книга «Максимы и мысли узника Святой Елены. Рукопись, найденная в бумагах Лас Каза. Перевод с английского». В английском предисловии к «Максимам и мыслям узника Святой Елены» сказано: «Известно, что после жестокого обращения, коему подвергся господин де Лас Каз со стороны британского министерства и губернатора острова Св. Елены, значительная часть бумаг Лас Каза была захвачена в Лонгвуде перед его отправлением на мыс Доброй Надежды. Часть из тех, что избегла просмотра и привезена была им в Европу, оказалась незаконно задержанной чиновниками, причем господину де Лас Казу не удалось осмотреть свои бумаги или составить опись оным. После же того, как были бумаги упакованы, их отослали к лорду Сидмуту, а Лас Каз был выслан из Англии в Голландию» [7, с. 32]. И далее: «Мы имеем серьезное основание полагать, что рукопись, каковую ныне мы публикуем, нам удалось получить благодаря тому, что один из чиновников министерства оказался нечистым на руку. По нашим предположениям, из сего драгоценного собрания Лас Каза было похищено несколько документов и среди них рукопись, которую мы публикуем. Быть может у вора они, в свою очередь, похищены были другим мошенником, что вполне вероятно, ибо мы получили рукопись от особы, пожелавшей остаться неизвестной и, коей мы за нее хорошо заплатили. (...)

Мы публикуем рукопись в том виде, в каком оная оказалась у нас и в каком пред сим попала в руки английских властей, без каких-либо примечаний, поелику несет в себе порою столько силы, мощи, точности, что не нуждается в комментировании. Что же касается стиля, характера, тона высказываний, содержащихся в этой рукописи, то оные по самой природе своей таковы, что способны и самых недоверчивых убедить в том, что рукопись подлинна».

Перед исследователями возникал и возникает вопрос: насколько был точен Лас Каз в своей фиксации высказываний Наполеона. «Теперь уже невозможно сомневаться в подлинности слов, приписываемых Лас Казом Наполеону, ибо те же беседы возобновлялись, те же мысли возникали вновь и получали дальнейшее развитие на страницах записок других членов свиты Наполеона на острове св. Елены», - пишет современный исследователь С.Н. Искюль [7, с. 10].

«Максимы и мысли» представляют собой сборник из 469-ти высказываний Наполеона, касающихся политики, истории, современности, литературы, философии. Высказывания эти не систематизированы, и связь между двумя высказываниями, стоящими рядом, обнаруживается крайне редко. Перед нами, как пишет С.Н. Искюль, свободное течение мыслей императора, не связанное условностями литературной формы, но относящееся, однако, как любые речи или высказывания политиков, к политическому дискурсу.

Bce, что Наполеон Бонапарт говорил или писал на Святой Елене, было предназначено и для современников, и для потомков. Поверженный император создавал миф о самом себе и своем владычестве в Европе, используя многочисленные элементы фантастического.

Например, император следующим образом оправдывал свое тираническое правление: «Когда народ в государстве развращен, законы почти бесполезны, ежели не управляется оно деспотически». А поскольку развращенным a priori можно назвать любой народ, то и деспотическое правление провозглашалось, таким образом, единственно целесообразным.Интересна в данном плане оговорка «почти»: Наполеон не говорит о том, что законы бесполезны в принципе, а лишь о том, что они почти бесполезны (у каждого правила есть исключения).

Себя Наполеон видел личностью совершенно исключительной, планетарного масштаба, имеющей право на всё, без каких бы то ни было ограничений. Так, он говорил: «С того времени, как я стал во главе государства, я советовался только с самим собой, и это меня вполне устраивало: совершать ошибки я начал только тогда, когда стал прислушиваться к тому, что говорят советники».

В языковом плане здесь представляет интерес многократное повторение местоимения «я» или его форм («меня»). Себя Наполеон считал неспособным на ошибку: согласно этой максиме, ошибаться император мог только тогда, когда прислушивался к чужим советам.

Перед нами отсылка к знаменитому латинскому афоризму (аллюзия): «Человеку свойственно ошибаться (Errare humanum est)», приписываемому Сенеке Старшему. У этого афоризма есть продолжение «Человеку свойственно ошибаться, но глупо упорствовать в своих ошибках (Errare humanum est, stultum est in error e perseverare)». Высказывание Наполеона содержит элементы фантастического: император заявляет, что никогда не ошибался по собственной вине (только по вине плохих советников). Следовательно, себя он считал неспособным на ошибки, что несвойственно человеку в принципе: латинская мудрость гласит, что все люди ошибаются, ошибки, как и грехи, свойст- 
венны человеческой природе. Не ошибаются только боги: однако себя Наполеон считал, по крайней мере, полубогом (особенно после того, как сам возложил на себя императорский венец). Общеизвестно, что императора Наполеона Бонапарта художники-современники часто изображали в облике бога войны Марса, подобно тому, как короля Людовика XIV (Короля-Солнце) изображали в образе златокудрого Феба-Аполлона.

«Errare humanum est, perseverare diabolicum (Человеку свойственно ошибаться, но настаивать на своей ошибке - от дьявола)», - эта латинская пословица имеет французский вариант («L'erreur est humaine, persévérer [dans son erreur] est diabolique». Смысл этого латинского изречения во французском варианте все тот же: «Ошибка - это свойство человека, настаивать на своей ошибке - от дьявола». Это изречение часто приписывают Сенеке, а иногда и Титу Ливию.

В частности, Тит Ливий говорил: «Venia dignus error is humanus (Каждая человеческая ошибка заслуживает снисхождения)». Близкое по смыслу изречение мы находим у Цицерона: «Is Cuiusvis errare: insipientis nullius nisi, in errore perseverare (Человеку свойственно ошибаться, но только безумец настаивает на своей ошибке) C'est le propre de l'homme de se tromper; seul l'insensé persiste dans son erreur».

Цицерон был большим знатоком древнегреческой литературы, и поэтому, возможно, это его высказывание - аллюзия к потерянной трагедии Эврипида «Ипполит».

Три столетия спустя после Цицерона святой Августин написал в своей «Исповеди»: «Нumanum fuit errare, diabolicum est per animositatem in errore manere. (Ошибка свойственна человеческой природе, но настаивать на своей ошибке из гордыни - дьявольское)».

Древнегреческий автор Менандр, живший в IV в. до Рождества Христова, говорил: «Ресcare idem bis, haud viri sapientis est»: «Commettre deux fois la même faute, ce n'est pas le fait d'un homme sage (Сделать два раза одну и ту же ошибку не свойственно мудрому человеку)».

В «Максимах и мыслях...» Наполеон отождествляет себя и Францию. Император повторяет: «Я и Франция...», «Меня и Францию...», например: «Накипь времен революции и грызня партий не могли бороться против меня и Франции». «Накипь времен революции» - это содержательно и идеологически важная метафора, в которую Наполеон Бонапарт вкладывает особый смысл, и, благодаря которой раскрывается отношение императора к революции.

«Накипь, оставшаяся на стенках кофейника» - так образно Наполеон Бонапарт описывает последствия Великой Французской революции и тем самым принижает те революционные процессы, которые породили и его самого, привели его на политическую сцену Европы и сделали одним из главных игроков на этой сцене. В то же время метафора «накипь революции» связана с кипением политических страстей, характерных для революционного процесса. Но при этом Наполеон Бонапарт подчеркивает, что и «накипь революции», и «грызня партий» не могли справиться с ним, с новым Сверхчеловеком, с будущим властителем Европы. Таким образом, Наполеон Бонапарт создает миф о самом себе - непобедимом и могущественном. Конечно же, этот миф - порождение стихии фантастического, сверхъестественного, иррационального.

Вообще личное местоимение «я» и притяжательное местоимение «мой» постоянно повторяются в речах Наполеона: «В Европе списывают мои законы, подражают моим учреждениям, завершают мои начинания, следуют моей политике и так далее, вплоть до тона, который задавал мой двор; значит, мое правление было не так уж плохо и нелепо, как о том говорят?» [7, с. 41]. Подобные повторы служат созданию мифа о Наполеоне Бонапарте как об идеальном властителе.

Император до такой степени отождествлял себя и Францию, что связывал ее величие и благополучие исключительно со своим правлением и своей персоной и не принимал в расчет других людей и обстоятельств. Такое отождествление правящей личности и государства, соединение императора с идеей идеально счастливой империи, некого утопического общества, которое живет и развивается по мановению правящей длани Бонапарта, является фантастическим, представляет собой элемент фантастики в политических высказываниях императора. Бонапарт рисовал утопическую картину счастливой Франции и блаженствующей под его скипетром Европы; в действительности картина была не такой радужной.

Те страны и культуры, которые оказывали сопротивление наполеоновской Франции, император называл низкими или недостойными государя из его династии: «Я совершил ошибку, вступив в Испанию, поелику не был осведомлен о духе нации. Меня призвали гранды, но чернь отвергла. Страна сия оказалась недостойной государя из моей династии». 
Таким образом, в политических речах Наполеона Бонапарта присутствовала совершенно фантастическая картина Европы, с исключительной по отношению к другим странам и народам Францией и неполноценными, убогими европейскими государствами: фанатичной Испанией, торгашеской Англией, трусливой и скучной Германией. Недостатки других стран и культур, действительно имевшие место, Наполеон изображал гипертрофированно преувеличенными, а о достоинствах предпочитал умалчивать. В результате Франция в политических речах Наполеона изображена идеальным государством-утопией, а сам император - полубогом.

Например, о Пруссии император говорил так: «Пруссия могущественна лишь на географической карте, политически же и нравственно это самая слабая из четырех великих держав, кои диктуют ныне законы всей Европе».

В адрес Испании Наполеон высказался более резко: «Всякое значение Испания уже потеряла: у нее не осталось ничего, кроме инквизиции да прогнивших кораблей».

Об англичанах император писал: «Иго англичан не по вкусу ни одной нации. Народы всегда страдают под властью этих англичан».

О мальтийских рыцарях Наполеон сказал так: «...Я уничтожил дворянство Мальты, хотя до этого ему удавалось сопротивляться силам Оттоманской империи».

О Нидерландах: «Нидерланды - всего лишь российская колония, где действует британское исключительное право».

О политической системе Европы: «Политическая система Европы внушает жалость: чем больше ее изучаешь, тем более опасаешься гибельных последствий, к которым она приводит».

«Инквизиция» и «прогнившие корабли» - это, согласно процитированному выше высказыванию Наполеона, символ современной ему Испании, тогда как Англия связывается исключительно с порабощением других народов («иго англичан»). Император выбирает образы-клише, которые характеризуют другие страны и народы однобоко, исключительно с нужной наполеоновской Франции стороны. Более чем характерно в данном случае выражение «всего лишь», употребленное в отношении Нидерландов: «всего лишь российская колония». Если другие государства так убоги и ничтожны, следовательно, завоевание их Наполеоном - благой шаг, спасение заблудших «детей».

Своим солдатам Наполеон сулил сказочные сокровища и богатейшие земли. Так, перед Итальянским походом Бонапарт говорил: «Солдаты! Вы наги; вас кормят впроголодь; правительство много задолжало вам и ничего не может дать. (...) Я поведу вас в самые плодоносные долины в мире. Перед вами откроются роскошные провинции и большие города; вы там найдете славу, почести и богатство. Неужели у вас недостанет мужества, доблести и стойкости?». Употребление превосходной степени имени прилагательного «самые плодоносные» можно назвать языковым элементом выражения категории фантастического. Бесспорно, долины Италии плодоносны, но Наполеон звал своих солдат в некое сказочное, чудесное пространство - самое плодоносное, самое роскошное, самое богатое.

Такая волшебная страна, конечно, один из элементов наполеоновской утопии, как и единая, благоденствующая под его скипетром Европа. Бонапарт предложил всем без исключения своим солдатам славу и богатство, но получили их лишь немногие. К тому же, предлагая армии богатство чужих стран, Бонапарт, по сути, подталкивал солдат к мародерству и грабежам. Однако за мародерство и грабежи солдата наполеоновской армии могли и расстрелять, если Бонапарту понадобилась бы поддержка населения завоеванных стран.

В этом фрагменте из обращения Наполеона к солдатам присутствует аллюзия на Ветхий Завет, в частности, на книгу Исхода, где говорится: «и иду избавить его от руки Египтян и вывести его из земли сей в землю хорошую и пространную, где течет молоко и мед...». От «руки египтян» пророк Моисей избавил народ Израиля и увел его из египетского плена в землю Ханаанскую. «Если Господь милостив к нам, то введет нас в землю сию и даст нам се - эту землю, в которой течет молоко и мед», - говорил Иисус Навин.

Наполеон Бонапарт предложил своим солдатам плодоносные долины Италии, земли богатые и обширные. В речах, обращенных к солдатам, Бонапарт использовал скрытые или явные отсылки к библейским цитатам (аллюзии, реминисценции), что вносило в политические высказывания генерала, а затем и императора элемент чудесного.

Отправляя своих солдат в Париж, к Директории, Наполеон говорил: «Солдаты! Горы отделяют нас от Франции. Если нужно, мы перелетим их на крыльях, чтобы оградить правительство и защитить свободу и Республику. Как только роялисты появятся - их дни будут сочтены». 
Языковые средства выражения элементов фантастики в политическом дискурсе

Создавая миф о себе как о сверхчеловеке, Наполеон одновременно создавал миф о Великой Армии, которая способна на все - в том числе и перелететь через горы. Оба этих мифа являются проявлением фантастического в политическом дискурсе Франции времен владычества Наполеона. Выражение «если нужно, мы перелетим их (горы) на крыльях» является гиперболой, с помощью которой создается атмосфера фантастического, формируется образ идеальной, непобедимой армии, состоящей из «гигантов», полубогов.

Кроме того, перед нами аллюзия к мифу о Дедале и Икаре. Как известно, хитроумный изобретатель Дедал сделал крылья, подобные птичьим, с помощью которых мог преодолевать природные препятствия. Прикрепив эти крылья, Дедал и его сын Икар покинули остров Крит, но Икар взлетел слишком высоко и разбился, а Дедал сумел долететь до Сицилии, где жил у царя Кокала и обучал местных мастеров. Дедал действительно преодолел пространство с помощью изобретенных им крыльев. Используя образы древнегреческой мифологии, Наполеон Бонапарт обожествляет не только себя, но и своих солдат, уподобляя их полубогам. В итоге создается фантастический образ «армии гигантов», полубогов, ведомой новым богом Марсом, величайшим полководцем всех времен и народов.

Когда Наполеон стал императором, то одним из его намерений было установить в Европе приоритет светской (императорской) власти над духовной. Но для этого, как справедливо указывал Д.С. Мережковский, нужно было что-то существенно изменить в христианстве. «Я старался не задевать догмата», - говорит Наполеон простодушно, как человек военный о невоенных делах. Но не задевать догмата было трудно - труднее, чем он думал, ведь к самому существу догмата относится вопрос: кто истинный владыка мира - Богочеловек или человекобог? Но он все-таки начал это трудное дело, объявил, что нет двух наместников Христа, Папы и кесаря, а есть единственный - кесарь. По Наполеоновскому катехизису: «Бог сделал императора наследником Своего могущества и образом Своим на земле» $[11$, с. 31$]$.

Наполеон рисует совершенно фантастическую картину благоденствующего мира, ставшего единой империей - его империей: «У меня проводились бы религиозные соборы наравне с сессиями Законодательного собрания; мои советы были бы представительством для всего христианства, а Папы лишь председательствовали в них; я открывал бы и закрывал эти собрания, утверждал бы и издавал бы решения, как это делали императоры Константин и Карл Великий; и ежели в прошлом эта верховность ускользала от рук императоров, то это потому, что они допускали ошибку, позволяя духовным вождям пребывать вдали от них».

Как видим, Наполеон уподобляет себя императорам Константину и Карлу Великому. Более того, император неоднократно указывал, что победили его не люди, а стихии: «В Москве уже весь мир готовился признать мое превосходство, стихии разрешили этот вопрос».

Метафора «стихии разрешили этот вопрос» указывает на то, что «сверхчеловек» Наполеон Бонапарт, неподвластный людям, стал жертвой стихий и, прежде всего, русского мороза (Генерала Мороза). Подобное мнение о себе, бесспорно, фантастично, является элементом фантастического в политических высказываниях, а также в публицистических и литературных произведениях императора.

Однако, создавая миф о самом себе, Наполеон уподобляет свою империю империи Карла Великого, а себя - великим императорам древности, например, Константину или Марку Аврелию. Среди европейских королей Наполеон уважал лишь Фридриха Прусского, которого считал выдающимся полководцем.

В плане литературном и языковом представляет интерес сама форма, выбранная Наполеоном для выражения своих политических и философских суждений - максимы, афоризмы. Максимы - это правила поведения, избранные человеком, обобщённая, лаконичная и отточенная мысль некоего автора, основные логические или этические принципы, которыми человек руководствуется в своих действиях.

Во французской литературной традиции были широко известны «Максимы, или моральные размышления» Франсуа де Ларошфуко, опубликованные в 1655 г. Наполеону, как и любому образованному европейцу, эти максимы были, бесспорно, известны.

В предисловии к своей книге Франсуа де Ларошфуко писал: «Я представляю на суд читателей это изображение человеческого сердца, носящее название «Максимы и моральные размышления». Оно, может статься, не всем понравится, ибо кое-кто, вероятно, сочтет, что в нем слишком много сходства с оригиналом и слишком мало лести. Пусть читатель помнит, что предубеждение против «Максим» как раз и подтверждает их, пусть проникнется сознанием, что чем запальчивее и хитроумнее он с ними спорит, тем непреложнее доказывает их правоту». 
Между наполеоновскими «Максимами» и творением Франсуа де Ларошфуко немало общего: так, например, Бонапарт называет властелином мира случай, а Ларошфуко - судьбу, по своей воле играющую людьми. Однако Ларошфуко предлагает читателям размышления философа, тогда как максимы Наполеона - это, прежде всего, афоризмы политика, часть политического дискурса первой половины XIX в.

Конечно, наполеоновские максимы восходят и к древнеримским крылатым изречениям. Наполеон любил воскрешать для современников мифы и достижения Римской империи, а себя самого часто сравнивал с императором Марком Аврелием. Поэтому наполеоновские максимы часто перекликаются и с древнеримскими афоризмами. В целом выбор лаконичной и отточенной литературной формы, такой как максимы, был связан со стремлением Бонапарта выражать свои мысли в высшей степени точно, заостренно и ясно, подобно мудрецам Древнего Рима.

Однако стремление Наполеона постоянно уподоблять Францию Древнему Риму является, на наш взгляд, проявлением фантастического. В реальности не бывает государств или империй, полностью подобных друг другу. Бонапарт идеализировал Древний Рим и его императоров, а вслед за этим создавал фантастический образ своей империи. Францию в период своего правления Наполеон изображает подобной идеализированному Древнему Риму, что является проявлением фантастического в политическом дискурсе наполеоновской эпохи.

«Даже когда я уйду, я останусь жить в умах людей как путеводная звезда их борьбы за свои права, мое имя станет их военным кличем, девизом их надежд», - писал Наполеон Бонапарт в «Мемориале святой Елены» в апреле 1816 г. Путеводная звезда - образ мифологический, уподобление своей роли в истории путеводной звезде - элемент фантастического. Под путеводной звездой в европейской христианской культуре понималась Вифлеемская звезда: «И се звезда, которую увидели они на Востоке, шла перед ними, как наконец пришла и остановилась над местом, где был Младенец».

Наполеон Бонапарт называет себя путеводной звездой для всего человечества, тем самым уподобляясь Сверхчеловеку, полубогу. Понятно, что такого рода уподобления (перифразы) относятся к сфере фантастического. Формирование наполеоновского мифа исследователи связывают с итальянской кампанией (1797 г.). Именно тогда генерал Бонапарт содействовал основанию газеты «Курьер итальянской армии», которая стала одним из средств формирования мифа о Наполеоне как о непобедимом полководце, Сверхчеловеке. В этой газете высоко оценивались организационные и прочие способности Бонапарта, благодаря которым он видел «дальше своих подданных».

Площадкой для формирования наполеоновского мифа можно назвать и бюллетени Великой Армии (Grande Armee). В этих бюллетенях рассказывалось не только о военных победах Великой Армии, но и о гении Наполеона Бонапарта, о его сверхчеловеческих способностях. Бонапарта называли наследником Карла Великого, его новым воплощением.

Сравнивали императора и со святыми мучениками. Так, кардинал Капрары (легат Пия VII) поведал Европе о существовании некоего Святого Наполеона, замученного в Александрии во времена императора Диоклетиана. Декретом от 9 февраля 1806 г. 15 августа, день рождения Императора, было назначено днем Святого Наполеона.

В антинаполеоновских памфлетах и пасквилях образ императора, напротив, демонизировался. Бонапарта называли «тираном», «иноземцем», «корсиканским чудовищем», «людоедом», сравнивали не с Карлом Великим или Марком Аврелием, а с Аттилой и Нероном. Таким образом, формировалась «черная легенда» об императоре. И «черную», и «белую» легенду о Наполеоне можно отнести к сфере фантастического.

Как уже говорилось выше, в 1823 г. был опубликован «Мемориал святой Елены» - посмертный памятник Наполеону, зафиксировавший «белую легенду» о нем как о Сверхчеловеке, полубоге. В «Мемориале святой Елены» свергнутый император выступает в роли мученика, поборника справедливости, освободителя народов Европы от гнета наследственных монархий, наконец - сверхчеловека. Все эти мифологизированные представления о Наполеоне Бонапарте относятся, бесспорно, к сфере фантастического.

Таким образом, к языковым средствам проявления фантастического в политическом дискурсе наполеоновской эпохи бесспорно можно отнести метафоры, эпитеты, гиперболы, гротеск, олицетворения, особые сравнения и повторы, а также аллюзии, реминисценции, явное и скрытое цитирование. Все это отражено в стиле политических речей, писем, максим Наполеона и его обращений к солдатам и современникам. Функционально этот стиль нацелен на самовозвеличивание императора, на идеализирование Франции и на манипулирование человеческим сознанием. 


\section{СПИСОК ИСТОЧНИКОВ И ЛИТЕРАТУРЫ}

1. Валгина Н.С. Теория текста: учебное пособие. М.: Логос, 2003. 280 с

2. Винокур Г.О. Об изучении языка литературных произведений // Винокур Г.О. Избранные работы по русскому языку. М., 1959.

3. Гальперин И.Р. Текст как объект лингвистического исследования. М: Наука, 2007. С. 56.

4. Деборд-Вальмор М. Стихотворения // Поэзия Франции. Век ХІХ. М.: Худ. литература, 1985. С. 57-66.

5. Долинин К.А. Интерпретация текста: Французский язык: Учебное пособие. Изд. 4-е. М.: КомКнига, 2010.

6. Дэвидсон Д. Что означают метафоры. М., 1990.

7. Искюль С.Н. Максимы и мысли узника Св. Елены/пер. с фр. С. Н. Искюль. СПб.: ИНАПРЕСС, 1995.

8. Лакофф Д., Джонсон М. Метафоры, которыми мы живем / Теория метафоры. М., 1990. 486 с.

9. Лингвистический энциклопедический словарь (ЛЭС). М.: Советская энциклопедия, 1990.

10. Маркова Н.А. Прагматические особенности художественного текста // Принципы изучения художественного текста: сб. науч. тр. Саратов, 1992.

11. Мережковский Д.С. Наполеон. М.: Республика, 1993.

12. Николина Н.А. Филологический анализ текста: учебное пособие. М.: Академия, 2003. 256 с.

13. Ожегов С.И. Толковый словарь русского языка, М.: Мир и Образование, Оникс, 2011. 736 с.

14. Откупщикова М.И. Синтаксис связного текста. Л., 1988.

15. Фесенко Э.Я. Теория литературы. М.: Академический проект, 2008.

16. Хализев В.К. Подтекст. // Краткая литературная энциклопедия. Т. 5. М.: Наука, 1968.

17. Чернявская В.Е. Дискурс власти и власть дискурса. Проблемы речевого воздействия. М.: Флинта: Наука, 2006. $136 \mathrm{c}$.

Синицына Ирина Андреевна, кандидат филологических наук, доцент кафедры иностранных языков ФГБОУ ВО «Московский государственный университет технологий и управления имени К.Г. Разумовского (ПКУ) 109004, Россия, г. Москва, ул. Земляной вал, 73 E-mail: renie80@mail.ru

Сафонов Максим Андреевич, старший преподаватель кафедры лингвистики и перевода ФГБОУ ВО «Российский государственный социальный университет»

129226, Россия, г. Москва, ул. Вильгельма Пика, 4/3

E-mail: em_kei@mail.ru

Усов Сергей Сергеевич, старший преподаватель кафедры лингвистики и профессиональной коммуникации ФГБОУ ВО «Московский государственный университет пищевых производств» 125080 Россия, г. Москва, ул. Врумбеля, 12.

E-mail: Ussr-usov@yandex.ru

Харченко Николай Леонидович, старший преподаватель кафедры иностранных языков

Московский государственный институт физической культуры, спорта и туризма им. Ю.А. Сенкевича 125499 Россия, г. Москва, Кронштадтский б-р, 43А

E-mail: m-rh@mail.ru

Янова Елена Александровна, старший преподаватель кафедры иностранных языков ФГБОУ ВО «Московский государственный университет технологий и управления имени К.Г. Разумовского (ПКУ)» 109004, Россия, г. Москва, ул. Земляной вал, 73 E-mail: renie_80@mail.ru

\section{N.L. Kharchenko, I.A. Sinitsyna, M.A. Safonov, S.S. Usov, E.A.Yanova LANGUAGE MEANS OF EXPRESSION OF FICTION ELEMENTS IN POLITICAL DISCOURSE}

DOI: 10.35634/2412-9534-2021-31-2-254-263

In this article we consider the category of fiction in political discourse - its language expression and the reasons for its appearance. In the process of research, we found out that one of the most important language means of expressing fiction in political discourse is metaphor and all its manifestations in the text. Metaphors convey a special, fantastic perception of the world. But, besides metaphors, the use of metonymy, hyperbole, litotes, comparisons, epithets, etc. also 
helps to form the category of the fantastic. We will consider the use of elements of the fantastic in political discourse on the example of the famous book "Maxims and Thoughts of Saint Helena Prisoner" in which Count de Las Cases, who voluntarily followed Napoleon Bonaparte in his exile, captured the emperor's statements, his aphorisms, fragments of political speeches, etc. Napoleon Bonaparte created authorial myths about himself, his rule and his army (the Great Army, Grande Armee), captured in his political speeches, letters, maxims and appeals to soldiers and contemporaries. From a literary and linguistic point of view, the very form chosen by Napoleon to express his political and philosophical judgments - maxims, aphorisms - is of interest. The result of our research is that the category of the fantastic in the political discourse of the Napoleonic era is the place to be and includes the use of metaphors, epithets, hyperbole, grotesques, personification, special comparisons and repetitions, as well as allusions, reminiscences, explicit and hidden quoting.

Keywords: political discourse, category of fiction, metaphor, the French language.

\section{REFERENCES}

1. Valgina N.S. Teoriya teksta: uchebnoe posobie [Text Theory: Study Guide]. M.: Logos, 2003. 280 p. (In Russian)

2. Vinokur G.O. Ob izuchenii yazyka literaturnyh proizvedeniǐ [On the study of the language of literary works] // Vinokur G.O. Izbrannye raboty po russkomu yazyku [Text as an object of linguistic research]. M., 1959. (In Russian)

3. Galperin I.R. Tekst kak ob"ekt lingvisticheskogo issledovaniya [Text as an object of linguistic research]. M: Science, 2007.S. 56. (In Russian)

4. Debord-Valmor M. Stihotvoreniya [Poems] // Poeziya Francii. Vek XIX [The poetry of France. XIX Century]. M.: Hudozhestvennaya literatura. 1985. S. 57-66. (In Russian)

5. Dolinin K.A. Interpretaciya teksta: Francuzskij yazyk: Uchebnoe posobie [Interpretation of the text: French: Textbook]. Izd. 4-e. M.: KomKniga, 2010. (In Russian).

6. Dehvidson D. Chto oznachayut metafory [What do metaphors mean]. M., 1990. (In Russian)

7. Iskyul S.N. Maksimy i mysli uznika Sv. Eleny/per. s fr. S. N. Iskyul' [Maxims and thoughts of the prisoner of St. Helena /translation from French by S. N. Iskyul]. Sankt-Petersburg: INAPRESS, 1995. (In Russian)

8. Lakoff D., Dzhonson M. Metafory, kotorymi my zhivem / Teoriya metafory. [The Metaphors We Live / Metaphor Theory]. M., 1990. 486 s. (In Russian)

9. Lingvisticheskij enciklopedicheskij slovar' [Linguistic Encyclopedic Dictionary]. M.: Sovetskaya enciklopediya, 1990. (In Russian)

10. Markova N.A. Pragmaticheskie osobennosti hudozhestvennogo teksta // Principy izucheniya hudozhestvennogo teksta [Pragmatic features of a literary text // Principles of the study of a literary text]. Saratov, 1992. (In Russian)

11. Merezhkovskij D.S. Napoleon [Napoleon]. M.: Respublika, 1993. (In Russian)

12. Nikolina N.A. Filologicheskij analiz teksta: uchebnoe posobie [Philological analysis of the text: a training manual]. M.: Academy, 2003. 256 p. (In Russian)

13. Ozhegov S.I. Tolkovyj slovar' russkogo yazyka [Explanatory Dictionary of the Russian Language], Moscow: Mir i Obrazovanie, Onyx, 2011. 736 p.

14. Otkupshchikova M.I. Sintaksis svyaznogo teksta [Connected text syntax]. L., 1988. (In Russian)

15. Fesenko E.Ya. Teoriya literatury [Theory of literature]. M.: Akademicheskij proekt, 2008 (In Russian).

16. Halizev V.K. Podtekst // Kratkaya literaturnaya enciklopediya [Subtext. // Brief literary encyclopedia]. V. 5. M.: Nauka, 1968. (In Russian)

17. Chernyavskaya V.E. Diskurs vlasti i vlast' diskursa. Problemy rechevogo vozdejstviya [The discourse of power and the power of discourse. Problems of speech exposure]. M.: Flinta: Nauka, 2006. 136 p. (In Russian)

Поступила в редакцию 19.10.2019

Sinitsyna I.A. Candidate of Philology, Associate Professor

Department of Foreign Languages,

K.G. Razumovsky Moscow State University of technologies and management (the First Cossack University)

Zemlyanoy Val, 73, Moscow, Russia, 109004

E-mail: renie_80@mail.ru

Saphonov M.A., Associate Professor, Department of Linguistics and Translation

Russian State Social University

Wilhelm Pieck st., 4/3, Moscow, Russia, 129226

E-mail: em_kei@mail.ru 
Usov S.S., Associate Professor,

Department of Linguistics and Professional Communication

Moscow State University of Food Production

Vrumbelja st., 12, Moscow, Russia, 125080

E-mail: Ussr-usov@yandex.ru

Kharchenko N.L., Associate Professor, Department of Foreign Languages

Moscow (Senkevich) State Institute of Physical Culture, Sports and Tourism

Kronshtadtskij blvd., 43A, Moscow, Russia, 125499

E-mail: m-rh@mail.ru

Yanova E.A., Associate Professor, Department of Foreign Languages

K.G. Razumovsky Moscow State University of technologies and management (the First Cossack University)

Zemlyanoy Val, 73, Moscow, Russia, 109004

E-mail: renie_80@mail.ru 